\title{
MOTORIC SPEED AND MANUAL DEXTERITY OF CHILDERN WITH IMPAIRED VISION
}

\author{
Dženana Radžo Alibegović ${ }^{1}$ \\ Hurma Begić
}

Original scientific paper

DOI: $10.21554 /$ hrr.041707

Faculty of Education and Rehabilitation Sciences, University of Tuzla, B\&H

Received: 01.02.2016

Accepted: 20.03.2017

\begin{abstract}
The aim of this study was to estimate the motoric speed and manual dexterity of children with visual impairments. The research is covered by a sample size of 35 participants with visual impairment, with ages between 7 and 15 years, of which 19 participants with visual impairment were male and 16 participants with impaired vision were female. The study was conducted in 17 primary schools in the municipality of Tuzla, Bosnia and Herzegovina. The results showed that the motoric speed and manual dexterity of children with visual impairment is evenly developed on the right and left hand, and also on both hands together and that there is a relationship between the motoric speed and manual dexterity of the right and left hand and both hands together.
\end{abstract}

Key words: motoric speed, motoric dexterity, hands of children with visual impairment

\section{INTRODUCTION}

Touching provides essential information to blind children about their surrounding world and about their daily activities. For children who are blind, it is necessary to use tactile function for their more independent functioning in everyday actions (Withagen, 2010). Common actions that can be easily solved with the help of vision can be complex if they are executed by touch (Jansson, 2008). Putting someone's hands on an object can be considered analogous to viewing that object with your eye. Some theorists suggest that there is a developing trend in the ability to use proprioceptive and tactile-kinesthetic senses in the years of learning (Gipsman, 1981). For the development of tactile-kinesthetic perception of blind children passive movements are very important, ie. the movements of arms, legs, head and neck and even the whole body, and these movements of the child's body are made by others (parents or education teacher). Such movements are the basis for the acquisition of tactile-kinesthetic experience, and therefore also for the tactile-kinesthetic learning (Stančić, 1991). The development of a hand greatly affects the development of the whole organism. Performing a variety of complex hand movements leads to the development of the cerebral cortex, which becomes the center of distinguishing a large number of stimuli that are received through the movements of the arm. A significant part of the motor zone of the cerebral cortex is centers for movements of the hand and fingers (Jablan, 2001). During the evolution of mankind, the hand was developed into the most perfect instrument of kinesiology. Along with these changes, the cortical representation of the movement also changed in favor of the areolas of hands, speech and eye movements. These parts of the body, reached the highest level of development in terms of anatomical and functional organization of praxis.

\footnotetext{
${ }^{1}$ Correspondence to:

Dženana Radžo Alibegović, Faculty of Education and Rehabilitation Sciences, University of Tuzla,

Univerzitetska 1, 75000 Tuzla, B\&H

E-mail:dzenana.radzo@untz.ba
} 
Mankind during its sociobiological development mastered the technique of using its own body parts, primarily hands for the purpose of using different objects but also in order to transfer messages or communication gestures, which apparently preceded verbal communication (Ocić, 1998). The interdependence of the motoric system and visual system affects the development of social communication and cognitive skills (Amerson, 1999). According Amerson (1999), "sensory input affects the motoric output and movement affects what is received through the sensory channels".

The importance of well-organized and skillful hand movement of blind children and those with greater visual impairment lies in the fact that the arm has to be a substitute for vision, as a means of contact and interaction with the environment. (Eškirović, Jablan and Vučinić, 2005). Perceiving objects with palpation is in principle no different from visual perception. The arm performs the same movement system that the eye performs while viewing objects. When palpating blind people can measure the width and length of the object, determine the shape, and compare it with other objects. According to Rewesz the hand is working, creating and recognizing. He was describing passive and active palpation. Passive palpation is done by hand which is stationary, and active palpation is done with the moving arm. In the position where vision brought both hands to the middle line, the fingers touch and to coordinate their use, hands of blind babies remain in the position at shoulder height. Results of the research conducted by Rogow on blind persons aged 3-19 years indicate a significant relationship between the manipulation of objects and success in speech. He also found that most of those who do not have good manipulation exhibit stereotyped movements. Finally, all subjects who successfully carried out the manipulation of objects manifested their desire to play with objects from their environment. Poor ability to fetch and poor control of arms are hindering coordination and displacement pattern, needed for crawling and movement. Movement is essential for understanding the permanence of the object for a blind child because only this is giving the child required information for the synthesis of experience. To a blind child the world appears as it is discontinued and it cannot attributed materiality to it. This can be understood as a conceptual problem - the child must conclude on the identity of the object only on the basis of sound (Bullingham, 1972; Dimčović, 1990; Fraiberg, 1977; Jablan, 1997).

In the perception of shapes, positions of objects and spatial relationships among objects, visually impaired children use analytical touch with whom hands in motion follow the contours of the object. So, the perception in this case is formed by combining successive senses of touch, which are accompanied by senses of movement of fingers and hands. If these movements are more consistent and performed at a higher speed, they will affect the possibility of acquiring new well systematized and organized information (Jablan, 2007). Proper coordination or coherent and rational finger movements of the right and left hand can significantly facilitate and speed up the process of learning, reading and writing of children with impaired vision. Therefore, motoric speed and dexterity directly affect the success of adoption knowledge of children with visual impairment (Radžo Alibegović, 2013). The aim of this study was to estimate the motoric speed and manual dexterity of children with visual impairments.

\section{METHODS}

\section{Sample of respondents}

The research is covered by a sample size of 35 participants with visual impairment, with ages between 7 and 15 years, of which 19 participants with visual impairment were male and 16 participants with impaired vision were female.

\section{The method of conducting the research}

The study was conducted in 17 primary schools in the municipality of Tuzla, Bosnia and Herzegovina. All subjects were tested individually in a separate room and in comfortable surroundings. The order of testing was such that it prevents consecutive activation of the same set of dimensions to avoid saturation effects and possible negative transfer. 


\section{Measuring instrument}

To estimate the motoric speed and manual dexterity of children with visual impairments Luria - Nebraska test for children (LNNB-C), more accurate, subtest C1 "motoric functions" was used, which refers to item number 1 (Golden, 1987). For collecting data on visual acuity analysis of medical records was used. Analysis of pedagogical and psychological documentation was used to collect data on sex and chronological age.

\section{Methods of data processing}

After the conduction of the research, the obtained data was processed by the computer statistical program SPSS 16.0 for Microsoft Windows. Basic statistical parameters were calculated, such as: minimum and maximum results, the arithmetic mean and standard deviation. To determine the significance of differences the t-test was used and by the Pearson and Spearman coefficient the statistically significant correlation between the observed variables was determined.

\section{RESULTS}

Based on the information that we got in our study, we wanted to determine:

-if the motoric speed and manual dexterity was accordingly developed on the right hand, or left hand and both hands together;

-if there exist some connection between the development of motoric skills and speed of the right, left and both hands.

Table 1. Motoric speed and manual dexterity of children with visual impairments

\section{Motoric speed and dexterity}

\begin{tabular}{lcccc}
\hline & Task number & $\overline{\mathbf{X}}$ & SD & $\mathbf{N}$ \\
Right & 1 & 0,49 & 0,70 & 35 \\
Left & 2 & 0,46 & 0,66 & 35 \\
Both hands & 3 & 0,40 & 0,60 & 35 \\
& & & \\
\cline { 2 - 3 } t-test and significances & $\mathrm{t}(1: 3)=0,83 ; \mathrm{p}=0,41-$ not significant \\
& $\mathrm{t}(2: 3)=0,53 ; \mathrm{p}=0,60-$ not significant \\
\hline
\end{tabular}

Table 1 shows the results of development of motoric skills and speed of the right, left and both hands of children with impaired vision. The t-test was used to determine the significance of differences between means for dependent samples. Based on the results in Table 1, we can conclude that the motoric speed and dexterity of children from our sample are equally developed on the right and left hand, and both hands together, because there are no statistically significant differences between the arithmetic means of the variables. 
Table 2. Relationship between motoric speed and skills of right, left and both hands

\begin{tabular}{llccc}
\hline & & Right & Left & Both hands \\
\hline Right & Pearson $\mathrm{r}$ & 1,00 & 0,84 & 0,57 \\
& $\mathrm{p}_{\text {sig }}$ & - & $\mathbf{0 , 0 0 * *}$ & $\mathbf{0 , 0 0 * *}$ \\
& $\mathrm{N}$ & 35 & 35 & 35 \\
Left & Pearson $\mathrm{r}$ & 0,84 & 1,00 & 0,49 \\
& $\mathrm{p}_{\text {sig }}$ & $\mathbf{0 , 0 0 * *}$ & - & $\mathbf{0 , 0 0 * *}$ \\
& $\mathrm{N}$ & 35 & 35 & 35 \\
Both hands & Pearson $\mathrm{r}$ & 0,57 & 0,49 & 1,00 \\
& $\mathrm{p}_{\text {sig }}$ & $\mathbf{0 , 0 0 * *}$ & $\mathbf{0 , 0 0 * *}$ & - \\
$\mathrm{N}$ & 35 & 35 & 35 \\
\hline
\end{tabular}

** Correlation is significant at a significance level of 0.01

To establish the correlation between the development of motoric skills and speed of the right, left and both hands the Pearson coefficient of linear correlation and its significance were used. Between the motoric speed and dexterity of the right hand and motoric speed and dexterity of the left hand there is a positive high correlation significant at the level of 0.01 . Between motoric skills and speed of the right hand and motoric skills of both hands there is a moderate positive correlation significant at the level of 0.01 . Also, between the motoric skills of the left hand and motoric skills of both hands there is a moderate positive correlation significant at the level of 0.01 .

\section{DISCUSSION}

Researches of development of blind children show that it is about equal to the development of children who do not have impairments, except tasks that require a basis of specific experiences. Belated mastering is most expressed in some types of motoric response, and that the fine motor coordination is easy developed only when a child has a wide experience in motoric activities. For skills with fine motor coordination and success in overcoming spatial relations, it was established that they are developing spontaneously, although usually at a higher age than in children that do not have visual impairments, those blind children which had adequate opportunities for rough motoric activity and which were allowed to freely explore their environment (Garrett and Levin, 1970).

The results of the study confirmed the conclusion that the motoric speed and manual dexterity of children with visual impairment in our sample are equally de- veloped on the right and left hand, and both hands together. It was also determined that there is a good connection between the development of motoric skills and speed of the right, left and both hands.

Each usable rest of vision greatly facilitates motoric development. For children with usable remains of vision visible stimulation can have a function as well as for children with normal sight, especially if it the vision is well-corrected. This refers to the fine motoric skills, except perhaps development of the finest precision motion seeking the perfect visual control (Oberman-Babić, 1987). In 2001, Jablan has examined the development and connection of motoric speed and manual dexterity of the hands of 95 blind students from first to eighth grade. The sample consisted of 60 boys and 35 girls. The average age of participants was 11.35 years. She came to the conclusion that the motoric speed and manual dexterity of blind children is equally developed on both hands as well as on the right and left hand, and between them there is a high correlation.

Radžo (2008) applied Ozeretzky kinesiology test on a sample of 58 school children, aged from 6 to 15 years (29 children with visual impairment and 29 children with normal vision). The author concluded that children with visual impairments exhibited significantly lower motoric skills compared to children with normal vision in total quotient of motoric skills (general motoric skills) and on all dimensions of psychomotor space. Visually impaired respondents successfully and in a timely manner did the assigned tasks with both hands in the psychomotor dimension B which is related to the coordinated dynamics of hands, which included solving problems with the left or right hand. 
Pavlović came to a similar conclusion (1987) when applied Ozeretsky test on a sample of 80 participants. Seen from a pedagogical point of view it is necessary to teach blind children all possible and relevant strategies in order to face the daily challenges, especially those children who are included in regular schools where they meet with a large number of tactile challenges, whenever they attempt to solve a task that includes touching, instead of seeing (McLinden and McCall, 2002). As part of the research project "Phenomenology of development obstructions and disruptions" realized at the Special Education Faculty in Belgrade from 2000 to 2005, a study was conducted which referred to the study of obstruction of kinesiology, with a sample of 86 students (55 visually impaired, 31 blind) from first to eighth grade. For the assessment of co-ordination, balance and praxis Ozeretzky test was also used. It was noticed that students with visual impairments incoordination and poor praxis activity is dominating. From the sign of dismaturation, diadochokinesis usually occurs, but also dislateralisation (Nikolić, Ilić-Stošović, 2007). Evenly and balanced development of tactile and motoric functions of blind children is the path through which gaining of experience takes place, and therefore determines also their psychosocial development (Jablan and Eškirović 2002).

\section{CONCLUSION}

By conducting this study ${ }^{2}$, we concluded that the motoric speed and manual dexterity of children with visual impairments are evenly developed. The results showed that there is a statistical link between the motoric speed and skills and the right hand, the motoric speed and dexterity and left hand as well as the motoric speed and dexterity and both hands. With $99 \%$ confidence we can conclude that the more developed motoric speed and dexterity of children with impaired vision of their left hand are, the more developed motoric speed and dexterity on the right hand or both hands will be.

\section{REFERENCES}

Amerson, M. J. (1999). Helping children with visual and motor impairments make the most of their visual abilities. RE:view, 31, 21-28

Bullingham, D.(1972). Psychoanalitic studies of the sighted and the blind international. New York: Universities Press.

${ }^{2}$ This research was conducted within the project "Motoric speed and manual dexterity of children with impaired vision", which is funded by the Federal Ministry of Education and Science in Bosnia and Herzegovina.
Dimčović, N. (1990). Kognitivni razvoj dece oštećenog vida u svetlu Pijažeove razvojne psihologije. Doktorska disertacija,Filozofski fakultet, Beograd.

Eškirović, B. Jablan, B. i Vučinić, V. (2005) Smetnje i poremećaji u razvoju kod dece oštećenog vida. U: Golubović S. i saradnici. Smetnje i poremećaji kod dece ometene u razvoju. Beograd: Defektološki fakultet, 75-146.

Fraiberg, S. (1977). Insights from the blind: Comparative studies of blind and sighted infants. New York: Basic Books.

Garet, F.Dž. i Levin, E. (1970) Psihološka praksa sa fizičkim invalidima. Beograd: Savezni odbor Saveza gluvih Jugoslavije.

Gipsman, S. C. (1981). Effect of visual condition on use of proprioceptive cues in performing a balancing task. Journal of Visual Impairment and Blindness, 75, 50-54.

Golden J.C. (1987). Luria-Nebraska Neuropsychological Battery; Children's Revision, Manual. Los aAngeles: Western Psychological services.

Jansson, G. (2008). Haptic as a substitute for vision. In M.A. Hersh i M.A. Johnson (Eds.), Assistive technology for visually impaired and blind people. London: Springer, 135-166.

Jablan, B. (2007). Motorne i taktilne funkcije kod slepe dece. Beograd: Fakultet za specijalnu edukaciju i rehabilitaciju.

Jablan, B. (1997). Blindizmi dece oštećenog vida. Magistarska teza. Defektološki fakultet, Univerzitet u Beogradu.

Jablan, B. (2001). Primena individualizovane nastave u vaspitnoobrazovnom radu sa učenicima ošte]enog vida. Aranđelovac: Januarski dani defektologa.

Jablan, B., Eškirović B. (2002). Taktilna i vizuelna efikasnost učenika sa oštećenjem vida. Nastava $i$ vaspitanje (3), 208219.

McLinden, M., McCall S. (2002). Learning throught touch: Supporting children with visual impairment and additional difculties. London: David Fulton.

Nikolić, S., Ilić Stošović, D. (2007). Smetnje vida kao uzrok smetnji motorike. Zbornik radova III ICEVI Balkanske konferencije „Tranzicija specijalne edukacije i rehabilitacije-nove mogućnosti“. Beograd: BIG štampa, 459-468.

Ocić, G. (1998). Klinička neuropsihologija. Beograd: Zavod za udžbenike i nastavna sredstva.

Oberman-Babić, M. (1987). Dijete oštećena vida u programima društvene brige o djeci predškolskog uzrasta. Tematska rasprava. Rano otkrivanje i praćenje djece s teškoćama u razvoju predškolskog uzrasta. Zagreb: Savez društava defektologa Hrvatske.

Pavlović, S. (1987). Osobenosti organizovanosti psihomotorike dece sa oštećenim vidom od 6 do 11 godina u odnosu na djecu sa neoštećenim čulima. Magistarski rad. Medicinski fakultet, Univerzitet u Beogradu.

Radžo Alibegović, Dž. (2013). Uticaj motoričkih i taktilnih funkcija na orijentaciju $i$ mobilitet kod djece oštećenog vida. Doktor $\neg$ ska disertacija. Edukacijsko-rehabilitacijski fakultet, Univerzitet u Tuzli.

Radžo, Dž. (2008). Psihomotorika djece oštećenog vida. Magistarski rad. Edukacijsko-rehabilitacijski fakultet, Univerzitet u Tuzli.

Stančić, V. (1991.) Oštećenja vida- biopsihosocijalni aspekti. Zagreb: Školska knjiga.

Withagen, A., Mathijs, P. J. Vervloed, Janssen Neeltje M., Knoors H., and Verhoeven L. (2010). Tactile Functioning in Children Who Are Blind: A Clinical Perspective. Journal of Visual Impairment and Blindness, 104, 43-54. 